\title{
ERRATUM
}

\section{Erratum to: Chronic Obstructive Pulmonary Disease Individualized Therapy: Tailored Approach to Symptom Management}

Dave Singh $\cdot$ Marc Miravitlles $\cdot$ Claus Vogelmeier

Published online: January 31, 2017

(C) The Author(s) 2017. This article is published with open access at Springerlink.com

Erratum to: Adv Ther

DOI 10.1007/s12325-016-0459-6

The following text should have been included in the Acknowledgments section of this publication:

The content of this paper is based on a symposium held at the ERS meeting in Amsterdam in September 2015. AstraZeneca was invited to carry out a courtesy scientific accuracy review prior to peer review for any inaccuracy related to the contents of the meeting, but not influencing the content.

The online version of the original article can be found under doi:10.1007/s12325-016-0459-6.

D. Singh $(\bowtie)$

University of Manchester, Manchester, UK

e-mail: dsingh@meu.org.uk

M. Miravitlles

Pneumology Department, Hospital Universitari Vall d'Hebron, CIBER de Enfermedades Respiratorias

(CIBERES), Barcelona, Spain

C. Vogelmeier

Department of Medicine, Pulmonary and Critical Care Medicine, Member of the German Center for Lung Research (DZL), University Medical Center Giessen and Marburg, Philipps-University Marburg, Marburg, Germany
Open Access. This article is distributed under the terms of the Creative Commons AttributionNonCommercial 4.0 International License (http://creativecommons.org/licenses/by-nc/4. $0 /$ ), which permits any noncommercial use, distribution, and reproduction in any medium, provided you give appropriate credit to the original author(s) and the source, provide a link to the Creative Commons license, and indicate if changes were made. 